Máté Zoltán

\title{
A Szolnok Televízió vételi lehetőségeinek és a músorok nézettségi szokásainak részletes elemzése
}

Zoltán Máté: Detailed analysis of the Szolnok Television reception opportunities and the habits of TV shows viewing

\section{Summary}

The treatise deals with the the views and preferences after the changes of Szolnok Television reception opportunities. With the using of the survey's results, it publish general result about the technical options of the Szolnok Television's reception and about preferences and views of the visible programs by comparing the hungarian large commercial channels' datas. Based on its own calculation methodology prepare a ranking of the discretion for the test channels and make statements the Szolnok Television connected further development opportunities.

Keywords: Marketing, Marketing Research, Survey, Views, Preference

\section{ÖSSZEFOGLALÓ}

A munka a Szolnok Televízió vételi lehetőségeinek változását követően a nézettségének és a tetszésének vizsgálatával foglalkozik. A kérdőíves felmérés eredményeit felhasználva általános eredményeket közöl a Szolnok Televízió vételének technikai lehetőségeiről, valamint a látható műsorok nézettségéről és tetszéséről, a magyarországi nagy kereskedelmi csatornák adataival összevetve. Saját számítási metodika alapján rangsort készít a vizsgált csatornák esetében a tetszésről, és megállapításokat tesz a Szolnok Televízió további fejlődési lehetőségeivel kapcsolatban.

Kulcsszavak: marketing, marketingkutatás, kérdőíves megkérdezés, nézettség, tetszés
2014 márciusában, áprilisában a Szolnok Televízió Zrt. megbízásából nézői, körben kutatás lebonyolítására került sor. A kutatás célja, hogy a digitális átállást követően, hogyan alakultak a vételi lehetőségek a Szolnok Televízió adásával kapcsolatban. A kutatás részcéljai között szerepel a Szolnok Televízió nézőinek nem, kor, és lakhely szerinti összetételének vizsgálata, valamint a nézettségi adatok összehasonlítása más kereskedelmi televíziós csatornák nézettségével.

A kérdőív szerkesztésénél és a kutatási metodika tervezésénél figyelembe vételre került, hogy a korábbiakban, és későbbiekben végzett illetve végzendő kutatások során lehetőség legyen a vizsgált témakörök időbeni változásának alakulását pontosan nyomon követni.

\section{KUTATÁSI MÓDSZERTAN}

Kutatási eljárás

Kutatási módszer

Megkérdezés ideje

Alapsokaság

Megkérdezés helye
Személyes megkérdezés kérdezőbiztosokkal

Kérdőív (10 kérdéscsoport, összesen 34 változóval)

2014. március - 2014. április

Szolnok megyei jogú város felnőtt lakossága

Lakosság arányosan az alábbi helyeken:

Szandaszőllős

Pletykafalu

Vasútállomás környéke

Széchenyi lakótelep

Belváros 
Máté Zoltán: A Szolnok Televízió vételi lehetőségeinek és a műsorok nézettségi szokásainak ...

Minta nagysága

Mintavételi eljárás Reprezentáció
200 fő, amiből következően az eredmények maximális hibahatára $\pm 4,00 \%$ (95\%-os megbízhatósági szinten.) Egyes kérdéseknél a tényleges hibahatár ettől nagyobb lehet, illetve több olyan kérdés is szerepelt, ahol több válasz adására volt lehetőség.

Véletlen mintavétel.

A minta nem reprezentatív, de jelentősen korrelációt mutat a kor, nem és a lakóhely, mint változók tekintetében.

\section{INFORMÁCIÓELEMZÉS}

Az egyes kérdésekre adott válaszok összesített darabszáma a 200-as mintaszámtól eltérhet, tekintettel arra, hogy a válaszadók közül azok, akik nem nézik a Szolnok Televízió műsorát, lefelé módosítják a válaszadói darabszámot, más kérdések esetében pedig az egy kérdésre adható több válasz, pedig felfelé módosíthatja azt. Az ábrákhoz kapcsolt elemszámok összege a mindenkori adott válaszok összesített darabszámát jelentik.

\subsection{Nemek aránya}

A vizsgált mintában a nemek aránya nő $52 \%$, férfi 48\%. A KSH 2011 es adatait figyelembe véve, ahol a nemek szerinti arány férfiak esetében $47,48 \%$ és a nők esetében $52,52 \%$, jelentős szignifikációt mutat. Ez azt jelenti, hogy a vizsgált minta, a nemek arányára vonatkozóan, a meghatározott hibahatáron belül maradva, reprezentativitást mutat.

\section{2. Életkor}

Az életkorral kapcsolatos adatok elemzésekor mindenképpen szükséges megvizsgálni a teljes sokaságra, Magyarország teljes lakosságára vonatkozó adatokat. (Forrás:KSH) Megállapítható, hogy a különböző kor szerinti idősávok megoszlása a $21 \%$ és $12 \%$ között mozog, nem túl nagy eltéréssel, tekintettel arra, hogy a $21 \%$-os érték a 0-20 éves korosztályt öleli fel, tehát 20 évet, míg a többi csak 10 évet. Amennyiben összevetjük a megkérdezettek kor szerinti eloszlását Magyarország teljes lakosságának kor szerinti eloszlásával megállapítható, hogy a 21-30, a 31-40, 41-50, valamint az 51-60 éves korosztály enyhén felülreprezentált, míg a többi enyhén alulreprezentált. Tekintettel arra, hogy a hirdetők számára az enyhén felülreprezentált korosztályok a kiemelten fontosak, megállapíthatjuk, hogy az alapsokaságtól való eltérés ebben az esetben nem befolyásolja negatívan a kapott eredményeket, sőt bizonyos értelemben a számunkra fontos korosztály véleményét tükrözi jobban.

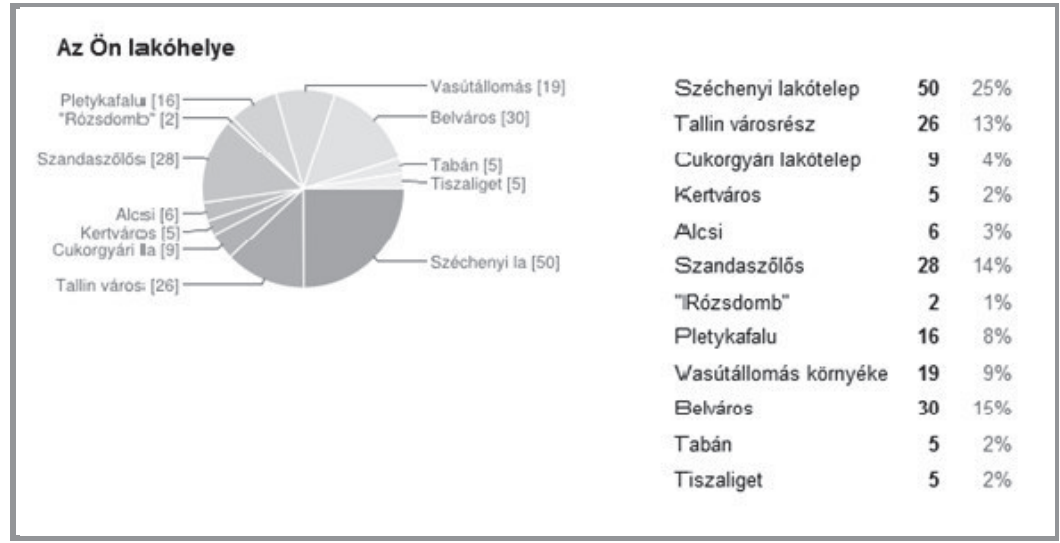

1. ábra: Lakóhely 
A minta lakóhely szerinti eloszlása a fenti ábra alapján a következő: a legnagyobb 25\%-os aránnyal azok rendelkeznek, akik a Széchenyi városrészen élnek, ami megegyezik az alapsokaság, tehát Szolnok városának teljes lakosságát jelentő arányokkal. A második, 15\%os résszel a belvárosban lakók száma, majd Szandaszőllős (14\%) és Tallin városrész (13\%) következik. A lekérdezés eredményességére utal, hogy annak ellenére, hogy összesen öt helyszínen került sor a megkérdezésekre, elmondható, hogy minden városrészen lakó megkérdezett megtalálható a mintában. A további megoszlás nem nagy szórást mutat, az arányok 9 és 2 százalék között oszlanak el. Elmondható, hogy a minta megfelelő arányban tartalmazza a különböző területeken lakók számát.

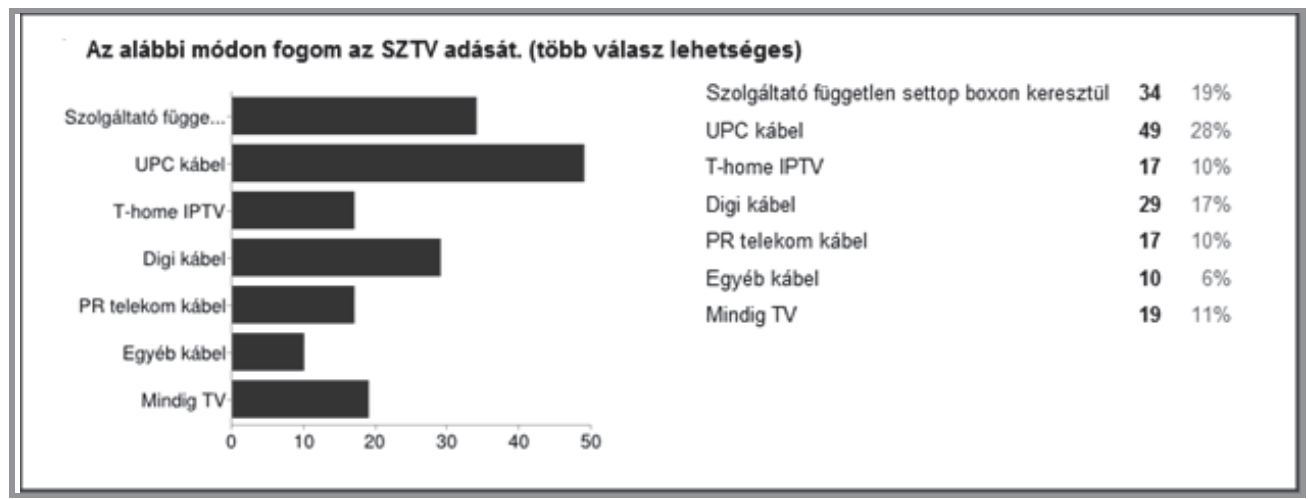

2. ábra: SZTV adás vételének módja

Forrás: Saját szerkesztés

Az összesen 175 válasz tartalma, hogy a leginkább használt elérési mód, a UPC kábelszolgáltatóhoz kapcsolódik (28\%), ezt követi a független settop boxon keresztül való televízió nézés (19\%), majd pedig a Digi kábelszolgáltató szolgáltatása. A negyedik a Thome és a PR telekom (10-10\%-al), végül az egyéb kábelszolgáltatók maradtak összesen 6\%os aránnyal.

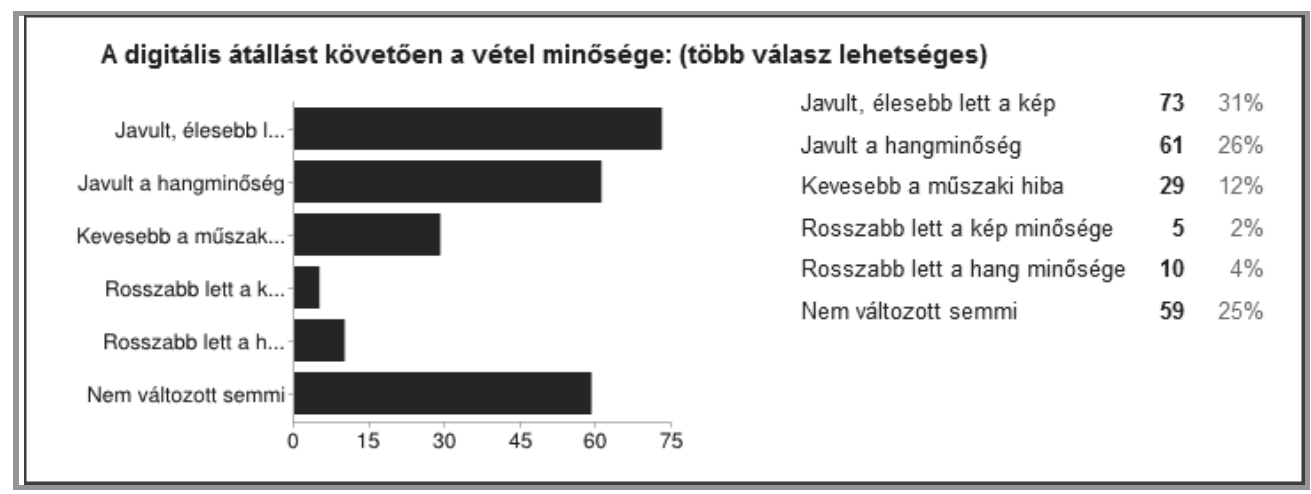

3. ábra: Vétel minősége digitális átállást követően 
Máté Zoltán: A Szolnok Televízió vételi lehetőségeinek és a műsorok nézettségi szokásainak ...

A digitális átállást követően, a nézői megítélés alapján, összességében javult a kép és hangminőség. elenyésző azok véleménye, akik a hang és képminőség romlását érzékelik.

A következőkben a különböző televíziós csatornák nézettségére vonatkozó adatok elemzésére kerül sor, először két összesített táblázatban.

A nézési gyakoriságot vizsgálva elmondható, hogy a legnagyobb folyamatos nézői táborral („6 mindig ezt nézem” válaszok) a klasszikus nagy kereskedelmi csatornák a TV2 (24\%) és az RTL (19\%) rendelkeznek. Ezt az élbolyt azonban szorosan követi egy másik csoport, ahol is az M1 (10\%), a Szolnok Televízió (9\%) a Hír TV (9\%) és Duna TV (8\%) jelenik meg. Elmondhatjuk tehát, hogy Szolnok Televízió adásainak van egy jelentős törzsnézői köre, mely stabil és a nagy országos adókkal is versenyképes. Mindez még inkább kidomborodik, ha a válaszok másik végletét („1 soha nem nézem”) vizsgálom, ahol is az M1-el való azonos nézettséggel, a nagy kereskedelmi adók mögött közvetlenül szerepel a Szolnok Televízió. A köztes válaszokat is elemezve megállapíthatjuk, hogy a Szolnokon élő válaszadók számára a Szolnok Televízió nézettsége az M1 csatornával közel azonos, és a vizsgált csatornák közül csak a két nagy kereskedelmi csatorna az RTL és a TV2 előzi meg őket.

Az előbbiekben már elemzett adatok egy másik dimenzióban való elemzésekor megállapítható, hogy a köztes értékek esetében, - ott ahol a nézettséget 4-5-re értékelték a megkérdezettek, - hasonlóan jól szerepelt az SZTV, hiszen az M1 és Duna TV-vel hasonló eredményeket tudott felmutatni, megelőzve olyan csatornákat, mint az ATV, ECHO TV, Hír TV.

A televízió csatornák tetszésének összevont adatait vizsgálva hasonló eredményekre jutunk, mint a nézettség vizsgálatakor. Megállapítható, hogy a TV2 és az RTL tetszése kimagasló, a többi vizsgált piaci szereplőtől jelentősen eltér pozitív irányba. Ezt követően szoros verseny alakul ki, a „6 a legjobban tetsző csatornám” kategóriában a Szolnok TV (11\%), az M1 (10\%), Hír TV $(10 \%)$, és a Duna TV (9\%) között. A további válaszlehetőségeket is vizsgálva, még erősebb ebben a csoportban az SZTV előnye, így megállapíthatjuk, hogy a válaszok alapján a Szolnok TV tetszése az RTL és a TV2 követően stabil harmadik helyen van.

A tetszési csoportokba rendezett adatok alapján az előző megállapítás itt is megmutatkozik, hiszen a SZTV adatok a magas tetszési indexek esetében (4-5-6) a harmadik helyen vannak, míg az alacsony pontok esetében (1-2-3) viszonylag alacsonyak, tehát viszonylag kevesen mondták, hogy nem tetszik a músor.

A nagy kereskedelmi csatornák tetszési adatainak vizsgálatát összevontan kezelve megállapíthatjuk, hogy rendkívül sok hasonlóságot mutatnak. Mindkettőnél kijelenthetjük, hogy a tetszés elszakad a többi versenyszereplőtől, a nemtetszés arány viszonylag kicsi, a többi csatornához viszonyítva, ugyanakkor a magas pontszámok jelentős arányt képviselnek a válaszokban. Az adatoból az túnik ki, hogy a TV2 nézői húségesebbek, és az általuk nézett músorok tetszése is magasabb, de csak egy kevéssel.

Az összesített nézettségi adatokat vizsgálva, elemezve felvetődött annak igénye, hogy alakítsunk ki rangsor a vizsgált televíziós csatornák tetszésére vonatkozóan. Az adatok áttanulmányozása után az alábbi számítási metodika került alkalmazásra. Minden csatorna tetszési adataira vonatkozóan meghatározásra került az átlag tetszési adat, mégpedig úgy, hogy a különböző értékekre kapott válaszok darabszáma került súlyozásra a skála értékeivel, majd az így kapott adatokat összege elosztotásra került az adott kérdésre kapott válaszok számának összegével. Így kialakult egy átlagos tetszést mutató viszonyszám, ami már rangsorolhatóvá tette a vizsgált csatornákat. 


\begin{tabular}{|c|c|c|}
\hline Rangsor érték & Csatorna & Átlagos tetszés \\
\hline 1. & TV2 & 4,1307 \\
\hline 2. & RTL & 4,1233 \\
\hline 3. & SZTV & 3,2088 \\
\hline 4. & M1 & 3,1503 \\
\hline 5. & Duna TV & 2,7600 \\
\hline 6. & Hír TV & 2,5270 \\
\hline 7. & ATV & 2,1610 \\
\hline 8. & ECHO & 2,0202 \\
\hline
\end{tabular}

4. ábra: Rangsor - A csatornák tetszése

A kutatás további szakaszában vizsgálatra kerültek még a Szolnok Televízió músorainak nézettségére és azok tetszésére vonatkozó információk. Összességében elmondható, hogy a müsorok nézettsége viszonylag jó átlagot produkál, de sajnálatos módon elég jelentős azon nézők arány, akik még egyáltalán nem látták a vizsgált müsorokat. Ha ezen nézők adatainak elhagyásával korrigálnánk adatainkat, akkor már sokkal magasabb átlagokat érhetnénk el. Így azonban olyanok szavazatai is bekerülnek a válaszok közé, akik úgy mondanak véleményt a músorokról, hogy még soha nem látták őket. További fejlődési lehetőség tehát, hogy a saját músorok promotálásával el kellene érni, hogy a nézők minél nagyobb számban ismerjék meg az eddig nem nézett műsorokat, növelve ezzel a nézettségüket.

A kutatás általános eredményeként megállapítható, hogy a Szolnok Televízió músorának, előkelő helye van a nagy kereskedelmi televíziók mögött a kulturális szolgáltatásban. Músorai jól strukturáltak, ugyanakkor fejlődési lehetőségeket is rejtenek magukban, ami a músorok több csatornán keresztül való promotálásával érhető el.

\section{IRODALOMJEGYZÉK}

[1] Hoffmann Márta, Kozák Ákos, Veres Zoltán (2000.): Piackutatás- Múszaki Könyvkiadó, Budapest

[2] Naresh K. Malhotra (1990.): Marketingkutatás- Műszaki Könyvkiadó, Budapest

[3] Paul A. Scipione (1994.): A piackutatás gyakorlata - Springer Hungarica Kiadó Kft., Budapest 